\title{
Oxygen deficit and $\mathrm{H}_{2} \mathrm{~S}$ in hemorrhagic shock in rats
}

Andry Van de Louw and Philippe Haouzi

\begin{abstract}
Introduction: Hemorrhagic shock induced $\mathrm{O}_{2}$ deficit triggers inflammation and multiple organ failure (MOF). Endogenous $\mathrm{H}_{2} \mathrm{~S}$ has been proposed to be involved in MOF since plasma $\mathrm{H}_{2} \mathrm{~S}$ concentration appears to increase in various types of shocks and to predict mortality. We tested the hypothesis that $\mathrm{H}_{2} \mathrm{~S}$ increases during hemorrhagic shock associated with $\mathrm{O}_{2}$ deficit, and that enhancing $\mathrm{H}_{2} \mathrm{~S}$ oxidation by hydroxocobalamin could reduce inflammation, $\mathrm{O}_{2}$ deficit or mortality.

Methods: We used a urethane anesthetized rat model, where $25 \mathrm{ml} / \mathrm{kg}$ of blood was withdrawn over 30 minutes. $\mathrm{O}_{2}$ deficit, lactic acid, tumor necrosis factor (TNF)-alpha and $\mathrm{H}_{2} \mathrm{~S}$ plasma concentrations (Siegel method) were measured before and after the bleeding protocol in control animals and animals that received $140 \mathrm{mg} / \mathrm{kg}$ of hydroxocobalamin. The ability to oxidize exogenous $\mathrm{H}_{2} \mathrm{~S}$ of the plasma and supernatants of the kidney and heart homogenates was determined in vitro.

Results: We found that withdrawing $25 \mathrm{ml} / \mathrm{kg}$ of blood led to an average oxygen deficit of $122 \pm 23 \mathrm{ml} / \mathrm{kg}$. This $\mathrm{O}_{2}$ deficit was correlated with an increase in the blood lactic acid concentration and mortality. However, the low level of absorbance of the plasma at $670 \mathrm{~nm}\left(\mathrm{~A}_{670}\right)$, after adding $N, N$-Dimethyl-p-phenylenediamine, that is, the method used for $\mathrm{H}_{2} \mathrm{~S}$ determination in previous studies, did not reflect the presence of $\mathrm{H}_{2} \mathrm{~S}$, but was a marker of plasma turbidity. There was no difference in plasmatic $A_{670}$ before and after the bleeding protocol, despite the large oxygen deficit. The plasma sampled at the end of bleeding maintained a very large ability to oxidize exogenous $\mathrm{H}_{2} \mathrm{~S}$ (high $\mu \mathrm{M}$ ), as did the homogenates of hearts and kidneys harvested just after death. Hydroxocobalamin concentrations increased in the blood in the $\mu \mathrm{M}$ range in the vitamin B12 group, and enhanced the ability of plasma and kidneys to oxidize $\mathrm{H}_{2} \mathrm{~S}$. Yet, the survival rate, $\mathrm{O}_{2}$ deficit, $\mathrm{H}_{2} \mathrm{~S}$ plasma concentration, blood lactic acid and TNF-alpha levels were not different from the control group.

Conclusions: In the presence of a large $\mathrm{O}_{2}$ deficit, $\mathrm{H}_{2} \mathrm{~S}$ did not increase in the blood in a rat model of untreated hemorrhagic shock. Hydroxocobalamin, while effective against $\mathrm{H}_{2} \mathrm{~S}$ in vitro, did not affect the hemodynamic profile or outcome in our model.
\end{abstract}

\section{Introduction}

The severity of a shock secondary to an acute hemorrhage is not simply dictated by the volume of blood loss [1,2]. Rather, the prognosis of a hemorrhagic shock is linked to a cascade of events, occurring during both the phase of bleeding and resuscitation, related to the magnitude of the oxygen deficit [3-6] and the resulting ischemic and postischemic inflammatory response $[7,8]$. Indeed, hemorrhagic shock precipitates inflammatory cascades that

\footnotetext{
* Correspondence: phaouzi@hmc.psu.edu

Pennsylvania State University, College of Medicine, Division of Pulmonary and Critical Care Medicine, Penn State Hershey Medical Center, 500 University Dr., PO Box 850, Hershey, PA 17033, USA
}

comprise the activation of stress transcriptional factors and up-regulation of cytokines synthesis $[9,10]$ leading to multiple organ failure [10]. Among the putative actors involved in the fatal course of an acute hemorrhage induced tissue ischemia/hypoxia, a novel candidate has been recently put forward: endogenous hydrogen sulfide [11,12]. Endogenous $\mathrm{H}_{2} \mathrm{~S}$, a newly described gaso-transmitter [13], has been shown to increase during and following an acute hemorrhage [11] and to act as a powerful pro-inflammatory agent in various animal models [14-17]. In humans, endogenous $\mathrm{H}_{2} \mathrm{~S}$ has been proposed 1) to increase in the blood up to $100 \mu \mathrm{M}$ concentrations during various forms of shock [18] and 2) to be a predictor of

\section{Biomed Central}


survival [18]. Although the mechanism of $\mathrm{H}_{2} \mathrm{~S}$ production remains to be clarified in shock, this by-product of cysteine metabolism appears to increase under hypoxic conditions $[19,20]$ and has been more recently suggested to contribute to the response to hypoxia [19,21-23], although this notion has been challenged [24-26]. One of the working hypotheses is that in hypoxic conditions, the level of $\mathrm{H}_{2} \mathrm{~S}$ oxidation in the cells and mitochondria is diminished [23]; in turn, the accumulation of this gas was proposed to transduce the physiological response to hypoxia in the vessels or the arterial chemoreceptors [23], but also an unwanted inflammatory response in other tissues [27].

Many questions on the role of $\mathrm{H}_{2} \mathrm{~S}$ in hemorrhage, however, remain to be clarified: there are, for instance, many reasons to believe that $\mathrm{H}_{2} \mathrm{~S}$ cannot accumulate in the blood $[28,29]$. Indeed, the view that $\mathrm{H}_{2} \mathrm{~S}$ increases in conditions associated with a hemorrhagic shock must be reconciled with the ability of the blood, the cytoplasm of most cells and the mitochondria to oxidize very large amounts of sulfide $[29,30]$, which should prevent $\mathrm{H}_{2} \mathrm{~S}$ from rising even at low $\mathrm{PO}_{2}$ [24]. One should also reconcile the view that $\mathrm{H}_{2} \mathrm{~S}$ concentrations could rise in the body and has deleterious effects with 1) the levels of sulfide found during $\mathrm{H}_{2} \mathrm{~S}$ intoxication (see [31] for discussion), which are much lower than those reported in shock [18], and 2) the observations that exogenous $\mathrm{H}_{2} \mathrm{~S}$ appears to be beneficial [32-34]. The clinical significance of such a beneficial effect remains the subject of debate [35].

We have recently investigated the effects of cobalt in the form of hydroxocobalamin on $\mathrm{H}_{2} \mathrm{~S}$ oxidation [30]. Injection of a large dose of vitamin B12 (at a level similar to that used in cyanide intoxication) dramatically increases the oxidative capacity of the blood and tissues (the kidney and to a lesser extent, the heart) for $\mathrm{H}_{2} \mathrm{~S}$ in the rat, possibly via the presence of oxidized cobalt [30]. Acting on $\mathrm{H}_{2} \mathrm{~S}$ oxidation in conditions associated with a reduction in oxidative mitochondrial metabolism may, however, represent a way to: 1) test the possible role of endogenous $\mathrm{H}_{2} \mathrm{~S}$ in clinically relevant conditions, such as hemorrhage induced tissue ischemia, and 2) evaluate potential novel therapeutic approaches in hemorrhagic shock.

The aim of this study was to determine in a model of untreated hemorrhagic shock in spontaneously breathing urethane anesthetized rats, wherein a large $\mathrm{O}_{2}$ deficit can be produced; 1 ) the putative changes in $\mathrm{H}_{2} \mathrm{~S}$ concentration in blood induced by this model of shock and 2) the potential benefit of large doses of vitamin B12 injected before the onset of the hemorrhage. The effects of the presence of $\mu \mathrm{M}$ levels of vitamin B12 in the blood and tissues on the survival at one hour, on the level of lactic acidosis, TNF-alpha and on $\mathrm{O}_{2}$ deficit accumulated during and following the period of hemorrhage were investigated, in keeping with the ability of blood and tissues (kidney and heart) to oxidize $\mathrm{H}_{2} \mathrm{~S}$. The possibility of bias accounting for the discrepancy between the lowexpected and high-reported changes in $\mathrm{H}_{2} \mathrm{~S}$ in humans was also investigated using the same methodological approaches as in published studies $[11,16,18]$. The hypothesis tested in this study is that $\mathrm{H}_{2} \mathrm{~S}$ increases along with inflammatory markers when $\mathrm{O}_{2}$ deficit develops during a hemorrhagic shock, and that increasing the oxidative property of the blood and tissues for $\mathrm{H}_{2} \mathrm{~S}$ by the presence of vitamin B12 could decrease these markers and improve survival.

\section{Materials and methods \\ Animal preparation}

After approval from the Pennsylvania State University College of Medicine Institutional Animal Care and Use Committee, a total of 17 adult Sprague-Dawley rats (470 \pm $43 \mathrm{~g})$ were prepared as follows: anesthesia was induced with $3.5 \%$ isoflurane in $\mathrm{O}_{2}$ followed by intra-peritoneal injection of $1.2 \mathrm{~g} / \mathrm{kg}$ of urethane (Sigma-Aldrich, St Louis, MO, USA). A polyethylene PE-50 catheter was inserted into the left femoral artery for blood withdrawal and arterial blood pressure (ABP) monitoring (Cybersense, Nicholasville, KY, USA). The animals were tracheostomized and the tracheostomy was connected to a small dead space two-way valve [24]. The inspiratory port of the valve was connected to a calibrated pneumotachograph (Hans Rudolph Inc., KS, USA, 8420 series, Kansas city, MO, USA) to measure inspiratory flow. The rats were breathing spontaneously in room air during the entire protocol. Their body temperature was monitored using a rectal probe and was kept at 35 to $36^{\circ} \mathrm{C}$ throughout the surgery and the hypovolemia using a pad heated at a constant temperature.

\section{Protocol}

Immediately after surgery, the rats received an intraperitoneal (I.P.) injection of either $140 \mathrm{mg} / \mathrm{kg}$ hydroxocobalamin (vitamin B12a, Sigma-Aldrich, $60 \mathrm{mg} / \mathrm{ml}$ ) in saline (vitamin B12 group, $n=9$ ), or an equivalent volume of saline $(2.3 \mathrm{ml} / \mathrm{kg}$, control group, $n=8)$. Each rat receiving saline or vitamin B12 was randomly chosen among a homogenous group of rats of similar age and weight. Thirty minutes after I.P. injection, hemorrhage was initiated by withdrawing $2.5 \mathrm{ml} / 100 \mathrm{~g}$ of blood over about 30 minutes as follows: $0.5 \mathrm{ml} / 100 \mathrm{~g}$ were withdrawn over 3 minutes, every 6 minutes ( 5 sessions). Blood gas analysis and lactate measurements were performed just before and at the end of the hemorrhage period (i-STAT-1 blood gas analyser, Abaxis, Union City, CA, USA). The first and last samples of blood withdrawn were also used for $\mathrm{H}_{2} \mathrm{~S}$ and vitamin B12 determinations 
(see below). Plasma was collected by centrifuging the blood 15 minutes at 13,000 rpm, and then frozen for the determination of TNF-alpha levels and of the ability of the plasma to oxidize $\mathrm{H}_{2} \mathrm{~S}$ (see below). No fluid was administered except for flushing the arterial catheter with a fixed volume of $0.2 \mathrm{ml}$ of heparinized saline after each period of bleeding. After the hemorrhage period, data were continuously recorded until the death of the animal.

\section{Measurements and data analysis}

The inspiratory flow $(\dot{\mathrm{V}})$ and arterial pressure signals were digitized by analog-to-digital converter at $200 \mathrm{~Hz}$ (LabView 8.5, National Instruments, Austin, TX, USA). Analysis of data was performed offline using Powerchart software (Chart 5, AD Instruments, Colorado Springs, CO, USA). Breathing frequency (f) and tidal volume (VT) were respectively determined using peak detection and integration of the inspiratory flow signal. Minute ventilation $(\dot{V} \mathrm{I})$ was computed in body temperature and pressure saturated (BTPS) conditions as $\mathrm{f} \times \mathrm{VT}$.

In 10 animals (4 controls and 6 hydroxocobalamintreated rats), a $7 \mathrm{ml}$ mixing chamber was connected to the expiratory port of the valve, where mixed expiratory gas composition was continuously sampled and analyzed (GEMINI, CWE Inc., Ardmore, PA, USA). $\mathrm{O}_{2}$ uptake $\left(\dot{\mathrm{VO}}_{2}\right)$ was computed in standard temperature and pressure, dry (STPD) condition using $\dot{\mathrm{V} I}$, the inspiratory and expiratory fractions of $\mathrm{O}_{2}$ and $\mathrm{CO}_{2}$. $\mathrm{VE}$ was computed as $\dot{\mathrm{VI}}_{\mathrm{BTPS}}\left(1-\mathrm{FIO}_{2}-\mathrm{FICO}_{2} / 1-\mathrm{FEO}_{2}-\mathrm{FECO}_{2}\right)$ and $\dot{\mathrm{VO}}_{2}$ as $\left(\dot{\mathrm{VI}}_{\mathrm{STPD}} \mathrm{FEO}_{2}\right)-\left(\dot{\mathrm{VE}}_{\mathrm{STPD}} \mathrm{FEO}_{2}\right)$. The same approach was used to calculate $\dot{\mathrm{VCO}}_{2}$ as $\dot{\mathrm{V}} \mathrm{E}_{\mathrm{STPD}} \mathrm{FEO}_{2}$. Oxygen deficit $(\mathrm{ml} / \mathrm{kg})$ was computed as the integral of difference between pre-hemorrhage $\dot{\mathrm{VO}}_{2}$ (averaged over five minutes) and $\dot{\mathrm{V}} \mathrm{O}_{2}(\mathrm{t})$ throughout the hemorrhagic period, then until death occurred. All signals were also displayed on line for monitoring.

Hydroxocobalamin concentrations in plasma and tissue homogenates were determined by spectrophotometric reading of the plasma at $525 \mathrm{~nm}$ (DU 530, Beckman Coulter, Danvers, MA, USA) as previously described [30].

The methylene blue method [36] was used for $\mathrm{H}_{2} \mathrm{~S}$ measurements in the plasma since this method was the one chosen in previous studies to establish the blood levels of $\mathrm{H}_{2} \mathrm{~S}$ increases in humans during shock $[16,18]$. We followed a similar protocol: after centrifuging $2.5 \mathrm{ml}$ of blood at 13,000 rpm for five minutes, $1 \mathrm{ml}$ of plasma was collected and $0.4 \mathrm{ml}$ of zinc acetate (1\%) was added to the plasma to trap $\mathrm{H}_{2} \mathrm{~S}$. Then, $100 \mu \mathrm{l}$ of a $20 \mathrm{mM}$ solution of $N, N$-Dimethyl-p-phenylenediamine sulfate (Sigma, St Louis, MO, USA) in 7.2 N hydrochloric acid
(Sigma), and $100 \mu \mathrm{l}$ of a $30 \mathrm{mM}$ iron chloride solution (Sigma) in $1.2 \mathrm{~N}$ hydrochloric acid were added to the plasma, producing a blue dye proportional to $\mathrm{H}_{2} \mathrm{~S}$ concentration. Throughout the procedure, every precaution was taken to prevent the samples from being in contact with air: the blood was collected in syringes that were immediately capped, and was then transferred to vials, which were completely filled, capped and centrifuged. After centrifugation, the plasma was collected and the reagents were immediately added. The same procedure (including centrifugation) was applied to phosphate-buffered saline (PBS) solution containing a known amount of $\mathrm{H}_{2} \mathrm{~S}$ (concentration $100 \mu \mathrm{M}$ ). The $\mathrm{H}_{2} \mathrm{~S}$ concentration was obtained after 20 minutes by adding $0.5 \mathrm{ml}$ of trichloroacetic acid (TCA) 10\% (to remove the proteins), centrifuging the solutions (10 minutes at 13,000 rpm) and reading the absorbance of the supernatants at 670 nanometers (spectrophotometer Beckman Coulter DU 530). A calibration curve for $\mathrm{H}_{2} \mathrm{~S}$ concentration was established, and for each experiment, a PBS solution was used as the blank.

In order to assess the ability of the plasma to oxidize exogenous $\mathrm{H}_{2} \mathrm{~S}, 0.6 \mathrm{ml}$ of plasma was mixed with $0.6 \mathrm{ml}$ of PBS. NaHS (sodium hydrosulfide hydrate, SigmaAldrich) solution was added to the diluted plasma, so that the final concentration of $\mathrm{H}_{2} \mathrm{~S}$ was $100 \mu \mathrm{M}$. The vials were entirely filled with diluted plasma and as soon as $\mathrm{H}_{2} \mathrm{~S}$ was added, the vials were capped to avoid contact with air. Two minutes later, residual $\mathrm{H}_{2} \mathrm{~S}$ concentration was measured at ambient barometric pressure after application of $0.5 \mathrm{ml}$ of TCA $10 \%$ (Sigma-Aldrich) prior to the final centrifugation (13,000 rpm for 10 minutes), and the absorbance was read at $670 \mathrm{~nm}$.

The same approach was used with the homogenates of hearts and kidneys harvested immediately after cardiac arrest. The organs were thoroughly rinsed in PBS, frozen in liquid nitrogen and stored at $-80^{\circ} \mathrm{C}$ for later analysis. They were then thawed in ambient air, weighed and homogenized (Tissue-Tearor, Biospec, Bartlesville, OK, USA) in PBS (50\% w/v for kidney, $25 \% \mathrm{w} / \mathrm{v}$ for heart). The homogenates were then centrifuged at 13,000 rpm for 15 minutes; $1.35 \mathrm{ml}$ of supernatant was collected and mixed with the corresponding volume of NaHS solution to obtain a final concentration of $100 \mu \mathrm{M}$ following the same procedure as for the plasma. Again, the vials were entirely filled with supernatant and as soon as $\mathrm{H}_{2} \mathrm{~S}$ was added, the vials were capped to avoid contact with air. Residual $\mathrm{H}_{2} \mathrm{~S}$ concentration was determined after two minutes.

As whole blood is known to readily oxidize $\mathrm{H}_{2} \mathrm{~S}$, we also sought to determine the resolution of the methylene blue method applied to the blood by adding known concentrations of $\mathrm{H}_{2} \mathrm{~S}$ in fresh blood from three sham rats and then measuring, for two minutes, $\mathrm{H}_{2} \mathrm{~S}$ concentrations using the 
very same procedure. Again the same measurements were made with the same timing using PBS solution.

TNF-alpha was measured in the plasma samples in duplicates using an ELISA OptEIA kit (BD Biosciences, San Diego, CA, USA).

\section{Statistical analysis}

All results are presented as mean $\pm \mathrm{SD}$. All parameters were compared between pre-bleeding and post-bleeding periods using a one-way ANOVA in each group. ABP, $\dot{\mathrm{VI}}$ and $\dot{\mathrm{V}}_{2}$ were also analyzed in each group before and after each of the five bleeding periods using ANOVA for repeated measurements; post-hoc comparisons were performed using a Bonferroni correction (SigmaStat 2.0, SPSS Inc, San Jose, CA, USA). Finally, the control and vitamin B12 groups were compared with ANOVA, while survival rates were compared between the two groups using a logrank test [37]. For all comparisons, $P<0.05$ was considered statistically significant.

\section{Results}

The shock model

Control animals $(n=8)$

Figure 1 displays recordings of the response to the hemorrhage protocol in two different rats, while Table 1 reports the averaged data. Hemodynamic, ventilatory and metabolic responses were qualitatively similar in all control rats. Typically, each of the five three-minute bleeding periods induced a drop in arterial pressure, minute ventilation, $\dot{\mathrm{V}} \mathrm{O}_{2}$ and $\dot{\mathrm{V}} \mathrm{CO}_{2}$. Between the bleeding periods, all the parameters tended to return progressively to their baseline values (Figures 1 and 2). This recovery was interrupted by the subsequent bleeding periods repeated after six minutes and was blunted over time. At the end of the bleeding periods (30 minutes), mean $\mathrm{ABP}, \dot{\mathrm{V}} \mathrm{I}, \dot{\mathrm{V}} \mathrm{O}_{2}$ and $\dot{\mathrm{V}} \mathrm{CO}_{2}$ were significantly reduced by $68 \%, 44 \%, 56 \%$ and $51 \%$ respectively (see actual data in Table 1). Blood lactic acid increased significantly $(P=0.001)$ (Table 1$)$. Two different profile patterns (Figure 1) were observed following the bleeding procedure: in five animals, arterial pressure increased slowly towards pre-bleeding levels before subsiding again until death occurred from primary respiratory or cardiac arrest, within two hours following the onset of bleeding. In the three remaining animals, arterial pressure, minute ventilation, $\dot{\mathrm{V}} \mathrm{O}_{2}$ and $\dot{\mathrm{V}} \mathrm{CO}_{2}$ continued to decrease until death (Figure 1), which occurred within one hour. The survival rate $v s$. time is shown in Figure 3. The $\mathrm{O}_{2}$ deficit which averaged $122 \pm 23 \mathrm{ml} / \mathrm{kg}$ at the end of the bleeding period (Figure 4 and Table 1) reached $338 \pm 88 \mathrm{ml} / \mathrm{kg}$ at the moment of death.

\section{Vitamin B12 treated rats $(n=9)$}

The absorbance spectra of the plasma of the animals treated with vitamin B12 clearly showed a peak of absorbance at $525 \mathrm{~nm}$ (Figure 5A), corresponding to a concentration of $185 \pm 216 \mu \mathrm{M} / \mathrm{l}$. No peak of absorbance at $525 \mathrm{~nm}$ was observed in the plasma of any of the control rats (Figure 5A).

As shown in Figure 2 and Table 1, the changes in $\mathrm{ABP}$, minute ventilation, $\dot{\mathrm{VO}}_{2}, \dot{\mathrm{V}}_{\mathrm{CO}}$ and lactate before, during and after the bleeding periods were similar in the group treated with vitamin B12 and in control animals. The time course of $\mathrm{O}_{2}$ deficit was also the same in the two groups of rats (Figure 4A). $\mathrm{O}_{2}$ deficit accumulated progressively during the bleeding period, reaching $118 \pm$ 45 at 30 minutes (Table 1 , NS vs controls, $P=0.98$ ). When vitamin $\mathrm{B} 12$ and control rats were combined, $\mathrm{O}_{2}$ deficit and lactate level at the end of bleeding were significantly correlated (Figure $4 \mathrm{~B}, \mathrm{r}^{2}=0.79$ ). The $\mathrm{O}_{2}$ deficit at the time of death was $265 \pm 30 \mathrm{ml} / \mathrm{kg}$ (Table 1 , NS $v s$ controls, $P=0.10$ ).

\section{$\mathrm{H}_{2} \mathrm{~S}$ measurements Control animals}

According to our standard curve, a concentration of $100 \mu \mathrm{M} \mathrm{H} \mathrm{H}_{2} \mathrm{~S}$ resulted in an absorbance of 1.41 at 670 $\mathrm{nm}$; the relationship between the concentration of $\mathrm{H}_{2} \mathrm{~S}$ and the absorbance was linear up to $3 \mu \mathrm{M}$ while it was possible to identify the presence of $\mathrm{H}_{2} \mathrm{~S}$ at a minimal value of $1.5 \mu \mathrm{M}$ (absorbance 0.005 ). We did not find any changes in the level of $\mathrm{H}_{2} \mathrm{~S}$ added to PBS which were analyzed following the very same procedure as the blood (including centrifugation): the absorbance of a solution of $\mathrm{H}_{2} \mathrm{~S}$ in PBS analyzed immediately after sampling from the "mother" solution dropped by $3.2 \%$ following the procedure applied to the blood $(n=12)$. Centrifugation for 10 minutes decreased the absorbance by $1.2 \%$. Absorbance readings of the plasma before the shock averaged $0.014 \pm 0.015$ (Figure 5B). According to the standard curve, such an absorbance would correspond to a theoretical $\mathrm{H}_{2} \mathrm{~S}$ concentration of $8.5 \pm 2.9$ $\mu \mathrm{M}$. However, the profile of absorbance over the visible spectrum was markedly different from that of a PBS solution containing $\mathrm{H}_{2} \mathrm{~S}$ at a concentration that would reach a similar absorbance at $670 \mathrm{~nm}$; as shown in Figure $5 \mathrm{~B}$, the absorbance of the plasma was high at $400 \mathrm{~nm}$ and decreased continuously as the wavelength was increased with a lack of peak of absorbance at $670 \mathrm{~nm}$, in major contrast to the PBS solution. In other words, in the absence of absorbance peak at $670 \mathrm{~nm}$, the value of absorbance of $0.014 \pm 0.015$ in the plasma did not reflect the presence of methylene blue - and thus $\mathrm{H}_{2} \mathrm{~S}$ at approximately $8 \mu \mathrm{M}$ - but should be viewed as a marker of turbidity. 


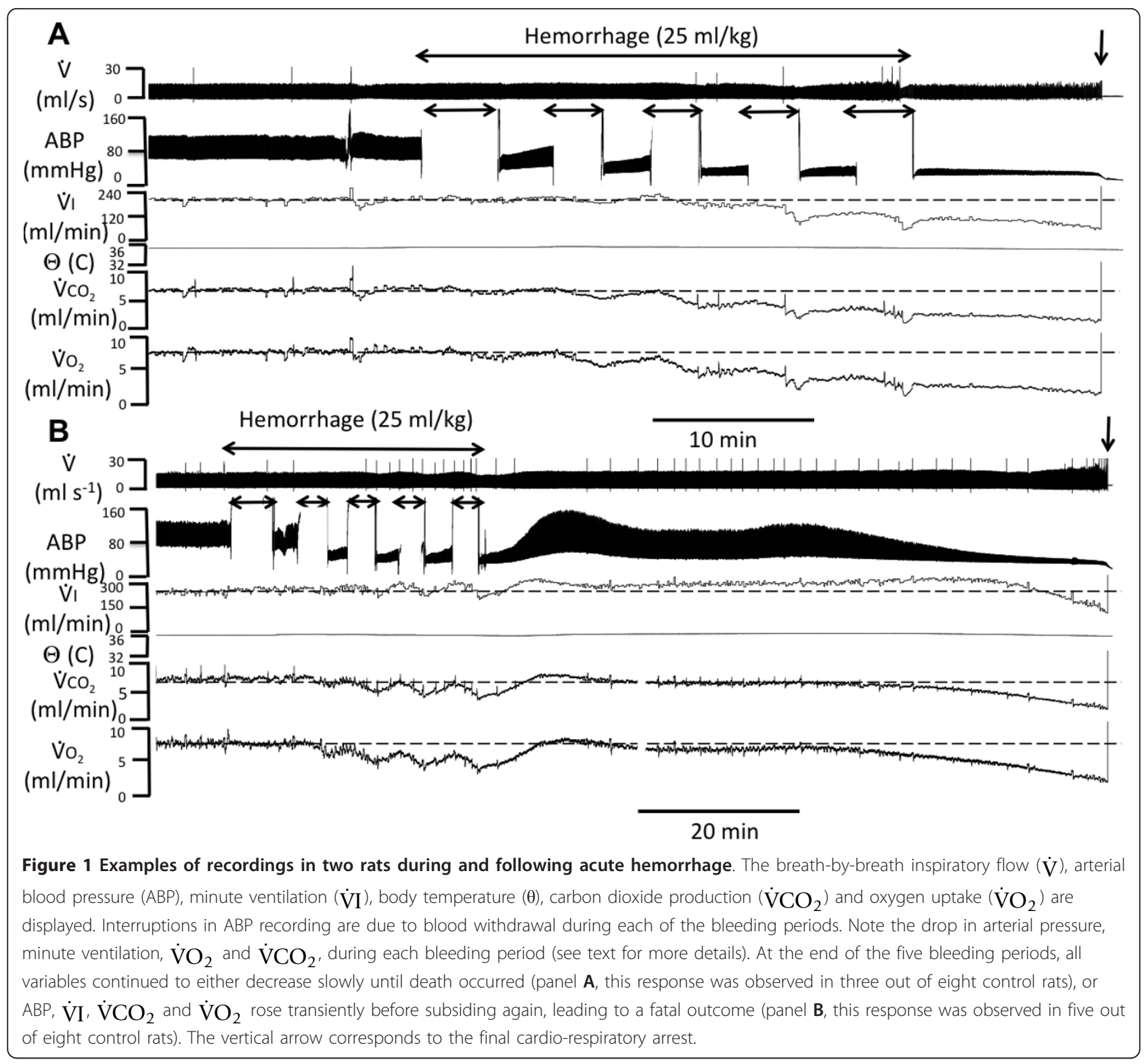

Table 1 Hemodynamic and metabolic variables before and at the end of the bleeding period.

\begin{tabular}{|c|c|c|c|c|}
\hline & \multicolumn{2}{|c|}{ Control $(n=8)$} & \multicolumn{2}{|c|}{ Vitamin B12 $(n=9)$} \\
\hline & Pre-bleeding & End of bleeding & Pre-bleeding & End of bleeding \\
\hline Mean ABP $(\mathrm{mmHg})$ & $80 \pm 12$ & $26 \pm 3^{*}$ & $79 \pm 7$ & $29 \pm 7^{*}$ \\
\hline Minute ventilation $(\mathrm{ml} / \mathrm{min})$ & $212 \pm 22$ & $118 \pm 50^{*}$ & $194 \pm 31$ & $123 \pm 39^{*}$ \\
\hline$\dot{\mathrm{V}} \mathrm{O}_{2}(\mathrm{ml} / \mathrm{min})$ & $7.18 \pm 0.45$ & $3.19 \pm 0.60^{*}$ & $6.79 \pm 0.67$ & $2.63 \pm 0.97^{*}$ \\
\hline$\dot{\mathrm{V} C O}{ }_{2}(\mathrm{ml} / \mathrm{min})$ & $6.55 \pm 0.60$ & $3.23 \pm 0.70^{*}$ & $6.42 \pm 1.14$ & $2.66 \pm 1.03^{*}$ \\
\hline Lactates $(\mathrm{mM} / \mathrm{l})$ & $1.88 \pm 0.50$ & $6.35 \pm 1.44^{*}$ & $1.53 \pm 0.21^{* *}$ & $6.63 \pm 2.09^{*}$ \\
\hline $\mathrm{PO}_{2}(\mathrm{mmHg})$ & $81 \pm 5$ & $90 \pm 11$ & $72 \pm 9^{* *}$ & $86 \pm 11^{*}$ \\
\hline $\mathrm{PCO}_{2}(\mathrm{mmHg})$ & $36 \pm 4$ & $31 \pm 7$ & $33 \pm 8$ & $29 \pm 5$ \\
\hline TNF-alpha (pg/ml) & - & $1,301 \pm 1,175$ & - & $732 \pm 869$ \\
\hline $\mathrm{O}_{2}$ deficit $(\mathrm{ml} / \mathrm{kg})$ & - & $122 \pm 23$ & - & $118 \pm 45$ \\
\hline
\end{tabular}

Values are mean $\pm \mathrm{SD} .{ }^{*} P<0.05$ vs pre-bleeding values. ${ }^{* *} P<0.05$ vs control rats. 


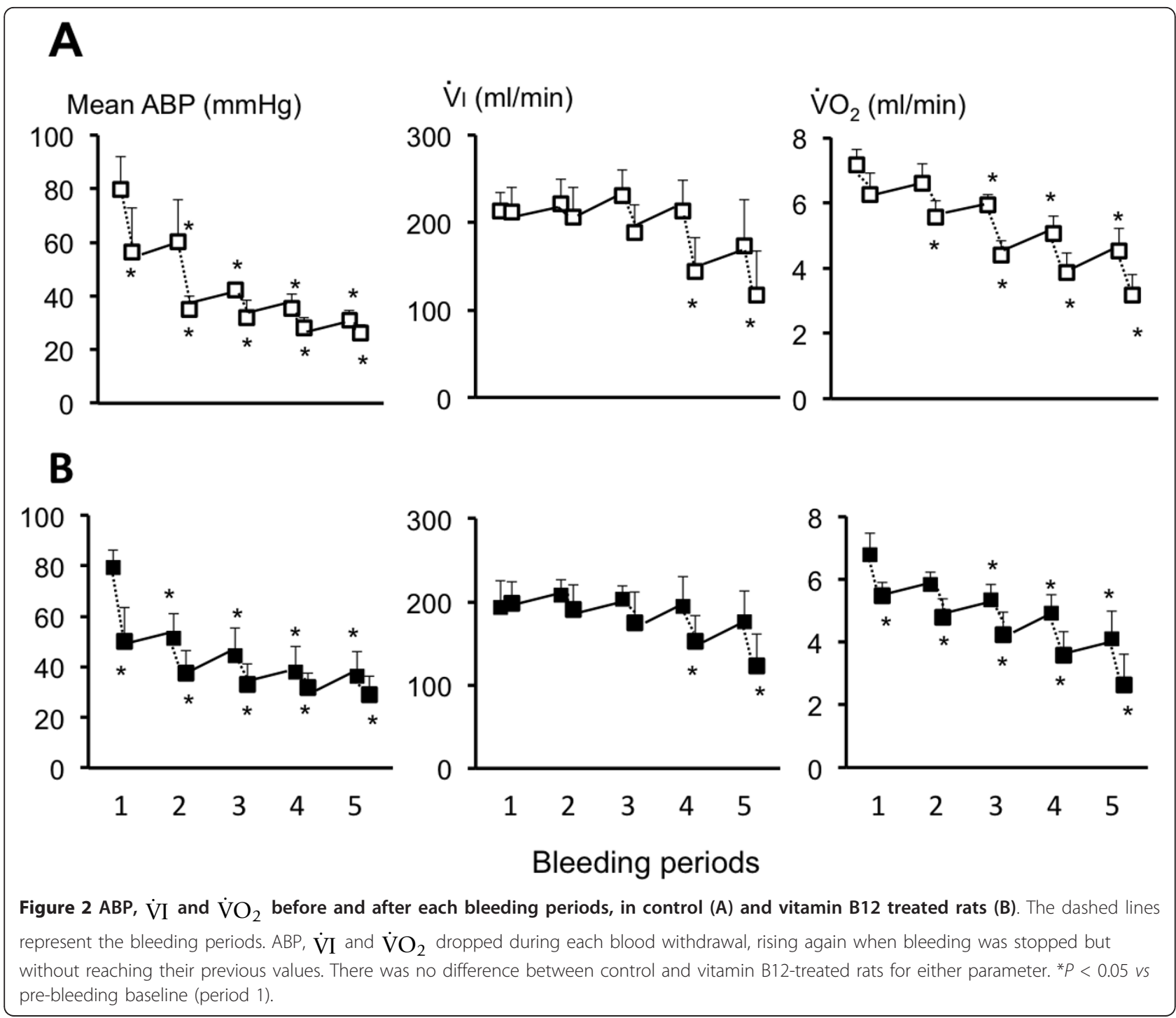

Similar results were found at the end of the bleeding period (when $\mathrm{O}_{2}$ deficit reached $122 \pm 23 \mathrm{ml} / \mathrm{kg}$ ) with an absorbance of $0.016 \pm 0.009$ at $670 \mathrm{~nm}$. No peak was observed and, just like before the bleeding period, a progressive decrease in absorbance from 400 to $700 \mathrm{~nm}$ was found (Figure $5 \mathrm{~B}$ ). This profile of absorbance and the lack of peak at $670 \mathrm{~nm}$ were observed in every animal with no exception.

\section{Vitamin B12 treated animals}

There was no significant difference between the absorbance at $670 \mathrm{~nm}$ in control animals and following vitamin B12, both prior $(0.017 \pm 0.009)$ and following $(0.029 \pm 0.018)$ the period of bleeding (Figure $5 \mathrm{~A})$. Just like in the control group and in major contrast to the PBS solution, no peak could be identified at $670 \mathrm{~nm}$ suggesting that $\mathrm{H}_{2} \mathrm{~S}$ concentration in the plasma, if any, could not be higher than a few $\mu \mathrm{M}$.

\section{Oxidation of $100 \mu \mathrm{M} \mathrm{H}_{2} \mathrm{~S}$ by the plasma before and during shock}

As shown on Figure 6A, two minutes after adding $0.1 \mathrm{ml}$ $\mathrm{H}_{2} \mathrm{~S}$ to pre-bleeding plasma to reach a final concentration of $100 \mu \mathrm{M}$, residual $\mathrm{H}_{2} \mathrm{~S}$ concentration was $9.2 \pm 0.9 \mu \mathrm{M}$ in the control plasma and $7.7 \pm 0.8 \mu \mathrm{M}$ in the plasma of the animals which received vitamin B12 $(P<0.01)$. No change in $\mathrm{H}_{2} \mathrm{~S}$ concentration was found in the PBS solution over two minutes. The ability of the plasma to oxidize $\mathrm{H}_{2} \mathrm{~S}$ remained unchanged at the end of the bleeding period, with residual plasma $\mathrm{H}_{2} \mathrm{~S}$ concentrations of $10.0 \pm 1.0$ and $7.2 \pm 1.7 \mu \mathrm{M}$ for the control and vitamin B12 groups respectively $(P<0.01)$. For the whole blood, the absorbance spectra of $\mathrm{H}_{2} \mathrm{~S}$ added in sham rat blood at three different concentrations $(50,100$ and $150 \mu \mathrm{M})$ is displayed on Figure 6B along with the corresponding residual $\mathrm{H}_{2} \mathrm{~S}$ concentrations. Within five minutes, initial 


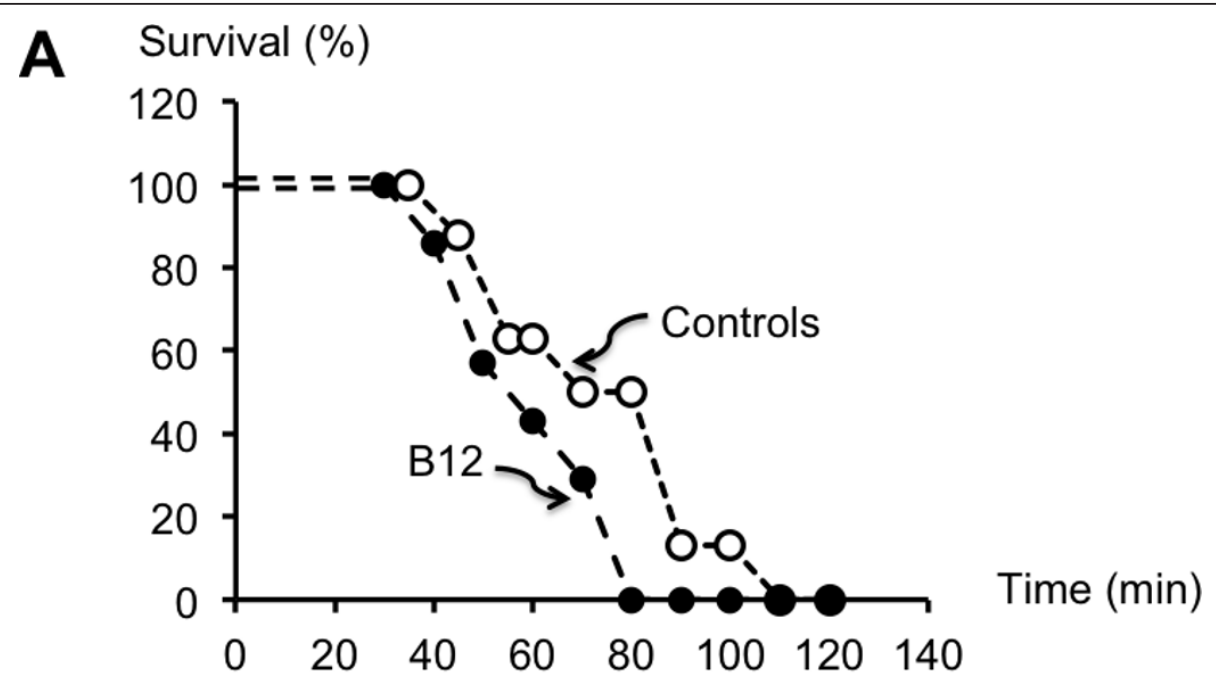

B

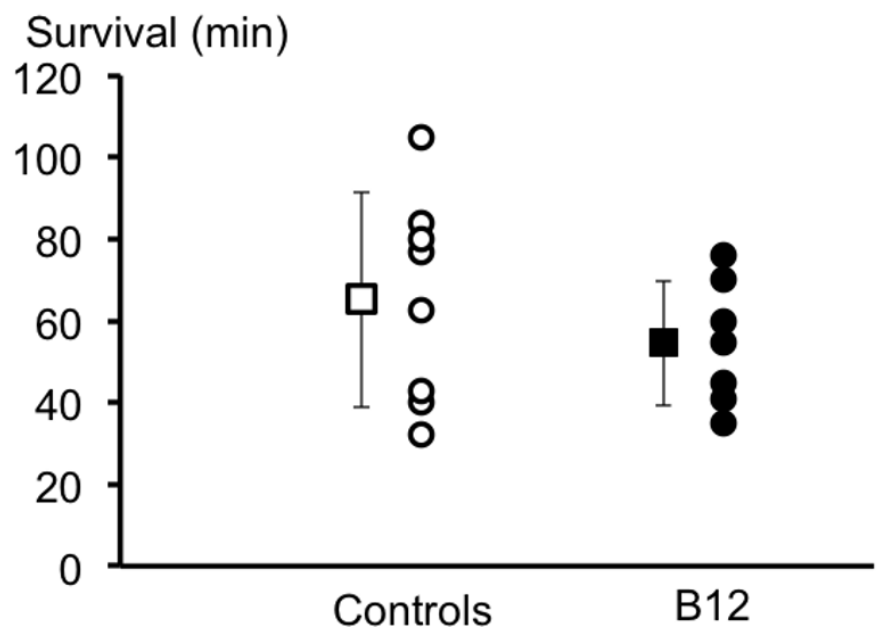

Figure 3 Survival rates. Panel A, survival rate (in \%) in the control (open circles) and vitamin B12-treated rats (closed circles). Time zero corresponds to the onset of the bleeding protocol. All rats survived the bleeding period (30 minutes), about 50\% were still alive after 60 minutes, and no rats survived after 120 minutes. There was no difference in the survival rates between the two groups (logrank test). Panel $\mathbf{B}$ displays the individual survival times for the two groups. There was no significant difference in the mean survival time between control and vitamin B12 treated rats ( $65 \pm 26$ vs $59 \pm 26 \mathrm{~min})$.

$\mathrm{H}_{2} \mathrm{~S}$ concentrations in blood of 50,100 and $150 \mu \mathrm{M}$ dropped by 90,92 and $75 \%$ respectively.

\section{Oxidation of $100 \mu \mathrm{M} \mathrm{H}_{2} \mathrm{~S}$ by tissue homogenates}

As shown on Figure 7B, two minutes after adding $0.15 \mathrm{ml}$ $\mathrm{H}_{2} \mathrm{~S}$ to the supernatant of kidney homogenates to reach a final concentration of $100 \mu \mathrm{M}$, residual $\mathrm{H}_{2} \mathrm{~S}$ concentration was $50.2 \pm 4.7 \mu \mathrm{M}$ in control kidney homogenates and $34.8 \pm 12.9 \mu \mathrm{M}$ in kidney homogenates of the animals which received vitamin $\mathrm{B} 12(P<0.01)$. In the same conditions, residual $\mathrm{H}_{2} \mathrm{~S}$ concentrations in heart homogenates were $31.3 \pm 0.9$ and $30.5 \pm 0.9 \mu \mathrm{M}$ for control and vitamin B12-treated rats respectively (Figure 7C, NS). In vitamin B12-treated rats, hydroxocobalamin concentrations were $47 \pm 57 \mu \mathrm{M}$ in kidney homogenates (Figure 7B), and below the threshold of detection $(30 \mu \mathrm{M})$ in heart homogenates except for two animals (Figure 7C). Concentrations did not change in the PBS solutions.

\section{Mortality and vitamin B12}

There was no difference in time to death $(59 \pm 26 v s 65 \pm$ $26 \mathrm{~min}$ ) or mortality rates over time between vitamin B12 and control rats (Figure 3).

\section{Plasma TNF-alpha}

There was very large intra-group variability but no statistically significant difference in TNF-alpha plasma levels between vitamin B12 treated and control rats $(P=$ 0.398, Table 1). 


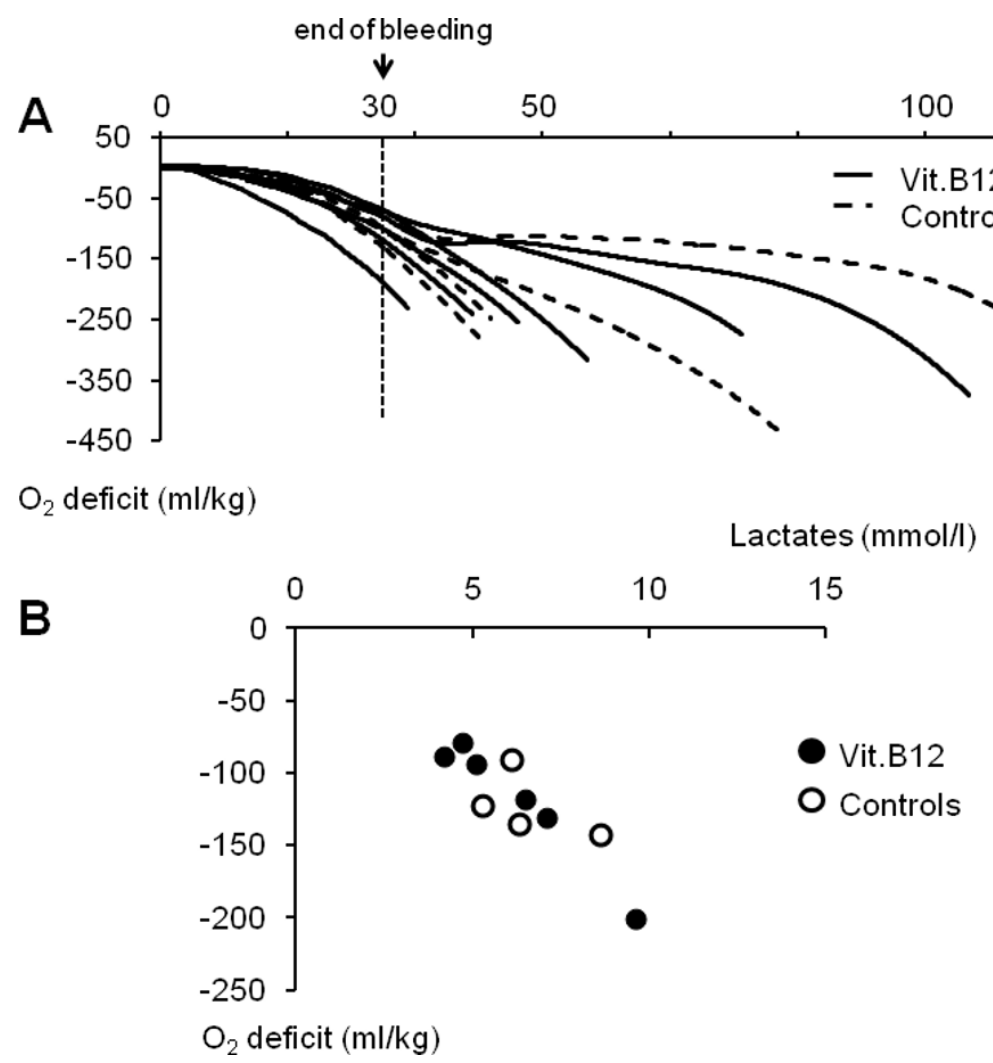

Figure 4 Oxygen deficit in control vs treated rats. Panel $\mathbf{A}$, time course of $\mathrm{O}_{2}$ deficit in four control (dashed lines) and six vitamin $\mathrm{B} 12$-treated (continuous lines) rats, from the onset of bleeding (time 0 ) to death. In all rats, $\mathrm{O}_{2}$ deficit accumulated continuously during the bleeding period reaching $120 \mathrm{ml} / \mathrm{kg}$ at the end of the bleeding protocol (vertical arrow). Following the bleeding period, $\mathrm{O}_{2}$ deficit continued to accumulate in a ramp-like fashion, while in the rats that survived much longer, $\mathrm{O}_{2}$ deficit remained constant. There was no significant difference in the time course of $\mathrm{O}_{2}$ deficit between control and vitamin B12-treated rats. Panel B, relationship between $\mathrm{O}_{2}$ deficit and plasma lactate levels at the end of bleeding periods in control (open circles) and vitamin B12-treated (closed circles) rats $\left(r^{2}=0.79\right)$.

\section{Discussion}

In major contrast to previous reports in humans [18] and in animal models [11], we did not observe any increase in blood $\mathrm{H}_{2} \mathrm{~S}$ concentration in a model of lethal untreated hemorrhagic shock in urethane anesthetized rats, despite major $\mathrm{O}_{2}$ deficit, hyperlactacidemia and systemic inflammation. In addition, following the bleeding period, the plasma of every animal, as well as the supernatants from the heart and kidney kept a very high ability of oxidizing/complex large (toxic) amounts of sulfide. Finally, following injection of a very large dose of vitamin B12, the ability to oxidize $\mathrm{H}_{2} \mathrm{~S}$ by the plasma and the kidney was enhanced in proportion to the local vitamin B12 concentration. However, the survival rate, $\mathrm{O}_{2}$ deficit or the various markers of the severity of the shock were not affected by the presence of $\mu \mathrm{M}$ levels of hydroxocobalamin. These findings do not support the hypothesis that endogenous $\mathrm{H}_{2} \mathrm{~S}$ does accumulate in the blood or in most tissues and contributes to the severity of hemorrhagic shock induced oxygen deficit $[11,18]$.

\section{Rat model}

To investigate the putative role of endogenous hydrogen sulfide during hemorrhagic shock induced cellular hypoxia, we used the urethane-anesthetized rat as an experimental model. Withdrawing $25 \mathrm{ml} / \mathrm{kg}$ of blood within 30 minutes produced a dramatic reduction in $\mathrm{ABP}, \dot{\mathrm{V}} \mathrm{O}_{2}$ and $\dot{\mathrm{V}} \mathrm{CO}_{2}$ along with an increase in lactic acid and in the respiratory quotient ratio. This hemorrhage protocol led to a fatal outcome in $50 \%$ of the animals within one hour following the bleeding onset, which paralleled the magnitude of $\mathrm{O}_{2}$ deficit and hyperlactacidemia. All animals died within two hours. This relatively low survival rate of hemorrhagic shock in rats compared to larger $[38,39]$ or non-anesthetized animals $[40]$ is not unexpected. Indeed, not only anesthesia alone is likely to affect the normal ability of the circulatory and respiratory systems to respond to an acute reduction in volemia $[31,41]$, but urethane, by itself, significantly blunts the normal cardio-vascular regulation [42]. Nevertheless, the fatal outcome we observed in our study appears to be 
B

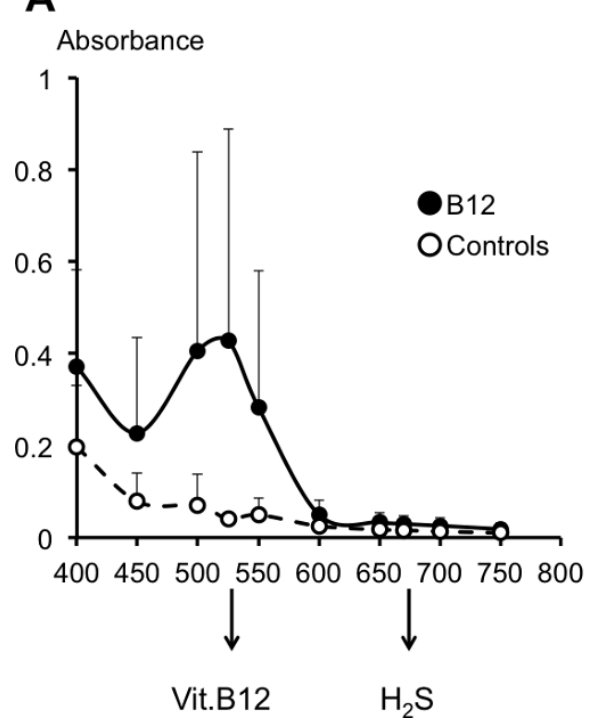

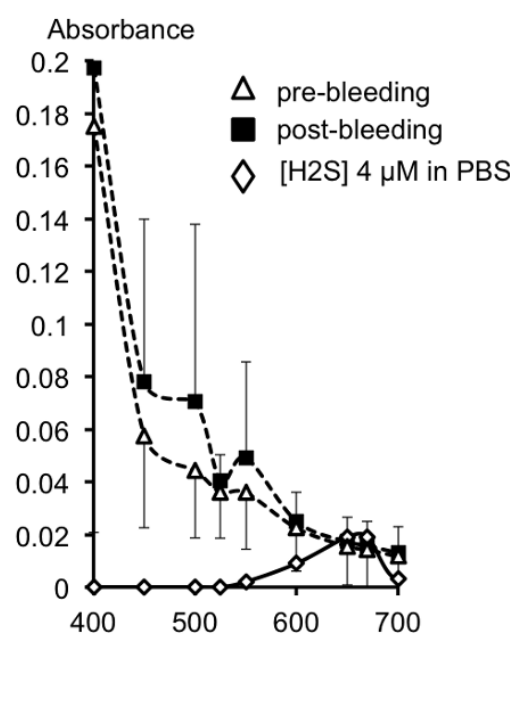

Figure $\mathbf{5}$ Absorbance of the plasma and $\mathrm{H}_{2} \mathrm{~S}$ concentrations. Panel $\mathbf{A}$, absorbance spectra of the plasma collected at the end of the overall bleeding period in control (open circles) and vitamin B12-treated (closed circles) rats. There was a clear peak of absorbance at $525 \mathrm{~nm}$ in vitamin B12-treated rats corresponding to a vitamin B12 plasma concentration of $185 \pm 216 \mu \mathrm{M} / \mathrm{l}$. No peak was observed in any of the control rats. At $670 \mathrm{~nm}$, that is, the absorbance wavelength of the methylene blue, no peak was observed, neither in control nor in the vitamin B12treated rats. Panel B, absorbance spectra, between 400 and $700 \mathrm{~nm}$, of the plasma of the control rats, before (open triangles) and at the end of the bleeding period (closed squares). The observed absorbance values at $670 \mathrm{~nm}$ would theoretically correspond to a $\mathrm{H}_{2} \mathrm{~S}$ concentration of around $4 \mu \mathrm{M} / \mathrm{I}$ in the dilute plasma (or $8 \mu \mathrm{M} / \mathrm{I}$ in the plasma, see text for additional comments), as illustrated using a control solution (phosphate-buffered saline, PBS) containing $\mathrm{H}_{2} \mathrm{~S}(4 \mathrm{\mu M}$ ) (open diamonds). The lack of peak of absorbance in the plasma at $670 \mathrm{~nm}$ along with the pattern of absorbance over the visible spectrum (continuous decrease of absorbance from $400 \mathrm{~nm}$ ) strongly suggest that it is the turbidity of the medium which could account for this apparent presence of $\mathrm{H}_{2} \mathrm{~S}$ in the plasma.

A

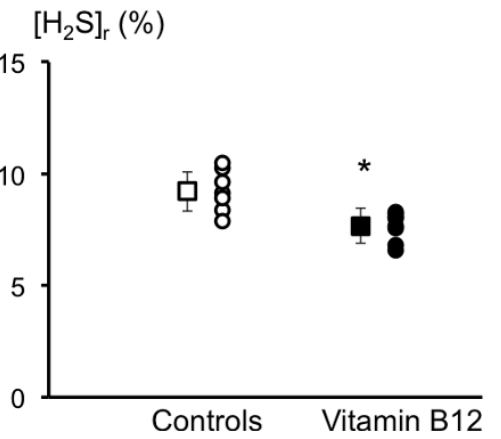

B

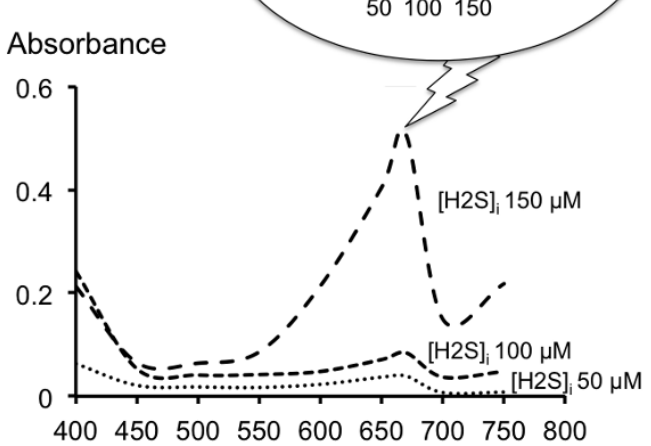

Figure 6 Plasma and $\mathrm{H}_{2} \mathrm{~S}$. Panel $\mathbf{A}$, residual $\mathrm{H}_{2} \mathrm{~S}$ concentration $\left(\left[\mathrm{H}_{2} \mathrm{~S}\right]_{r}\right)$, two minutes after addition of $100 \mu \mathrm{M} \mathrm{H}_{2} \mathrm{~S}$ in the plasma of control (open circles) and vitamin B12-treated (closed circles) rats. $\left[\mathrm{H}_{2} \mathrm{~S}\right]_{\mathrm{r}}$ is expressed in percentage of the concentration of $100 \mu \mathrm{M}$ present in a control PBS solution analyzed at the same time as the plasma. Within two minutes, $\mathrm{H}_{2} \mathrm{~S}$ concentrations decreased by more than $90 \%$ in control and vitamin B12-treated rats respectively, with a significant difference between the two groups ( ${ }^{*} P<0.05$ ). Panel $\mathbf{B}$, absorbance spectra of $\mathrm{H}_{2} \mathrm{~S}$ added to sham rat whole blood at 50, 100 and $150 \mu \mathrm{M}$ and measured after two minutes. In the inset, the percentage of residual $\left[\mathrm{H}_{2} \mathrm{~S}\right]\left(\left[\mathrm{H}_{2} \mathrm{~S}\right]_{\mathrm{r}}\right)$, corresponding to the absorbance at $670 \mathrm{~nm}$, is shown for each initial concentration. Depending of the initial $\left[\mathrm{H}_{2} \mathrm{~S}\right]\left(\left[\mathrm{H}_{2} \mathrm{~S}\right]_{\mathrm{i}}\right)$, exogenous $\mathrm{H}_{2} \mathrm{~S}$ concentrations decreased between 92 and 75\%. 


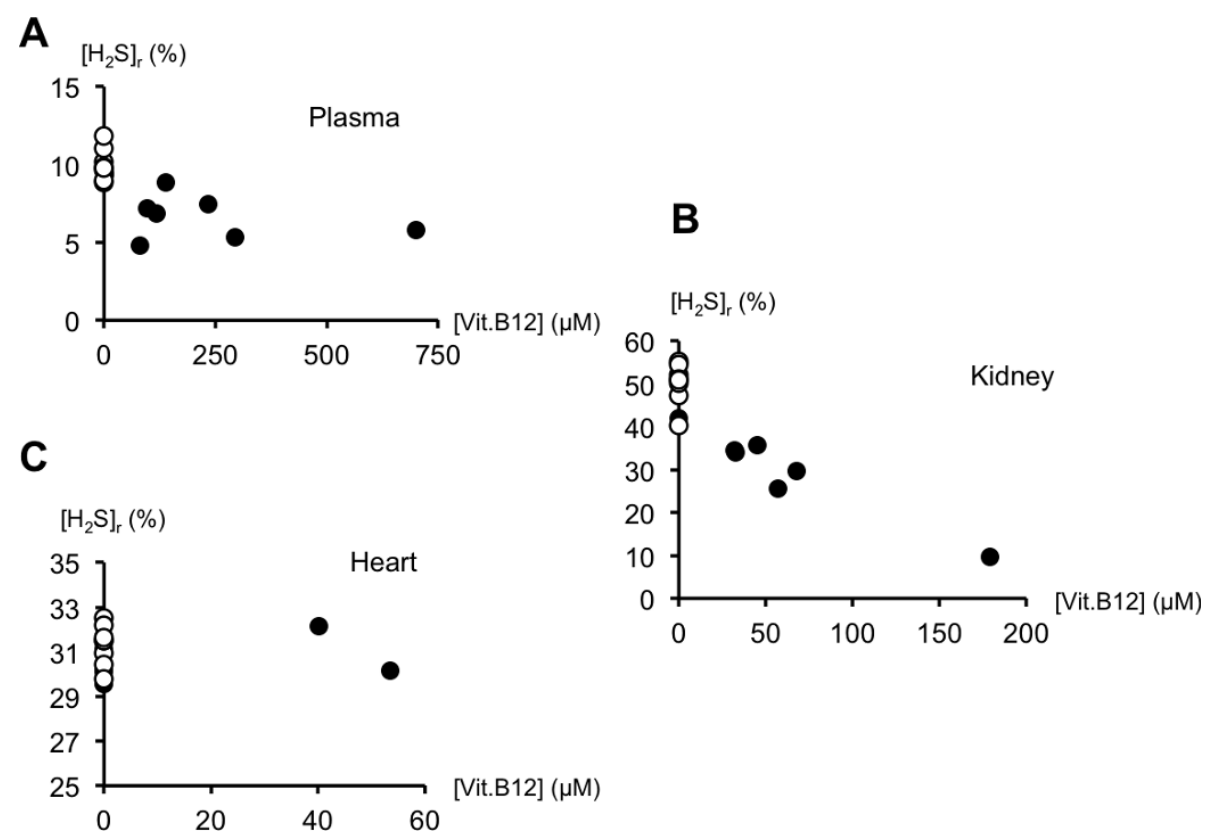

Figure 7 Ability of plasma and tissue homogenates to oxidize/complex $\mathrm{H}_{2} \mathrm{~S}$. Individual relationship between vitamin $\mathrm{B} 12$ concentration and residual $\mathrm{H}_{2} \mathrm{~S}$ concentration $\left(\left[\mathrm{H}_{2} \mathrm{~S}\right]_{\mathrm{r}}\right.$ ) determined two minutes after addition of $100 \mu \mathrm{M} \mathrm{H} \mathrm{H}_{2} \mathrm{~S}$ in the plasma (Panel $\mathbf{A}$ ), in the supernatant of kidney homogenates (Panel B) and heart homogenates (Panel C) in all the control (open circles) or vitamin B12-treated (closed circles) rats. [ $\left.\mathrm{H}_{2} \mathrm{~S}\right]_{\mathrm{r}}$ is expressed in percentage of the initial concentration of $100 \mu \mathrm{M}$ present in a control PBS solution analyzed at the same time as the medium. In the presence of vitamin B12, very large amounts of $\mathrm{H}_{2} \mathrm{~S}$ can be oxidized both in the plasma and in the kidney. In the heart, the concentration of vitamin $\mathrm{B} 12$ was too low to be measured by our method (except for two rats) and no visible effect on high $\mu \mathrm{M}$ concentration of exogenous $\mathrm{H}_{2} \mathrm{~S}$ could be identified (see text for additional comments).

both quantitatively and qualitatively similar to that observed in larger mammals $[1,3,5]$. A number of characteristics of our model should, however, be discussed. First, $\mathrm{O}_{2}$ deficit per kilogram was much larger for a given volume of blood withdrawn than in larger animals, such as pigs [1] or dogs [4,5]. This larger reduction in $\dot{\mathrm{VO}}_{2}$ during and following the hemorrhage was associated to a higher baseline specific (per kilogram) metabolic rate, typical of small mammals, akin to hypoxia induced metabolic depression [43-46]. More specifically, resting $\mathrm{V}_{2}$ in our rat model averaged $15 \mathrm{ml} / \mathrm{kg}$ (about four times the expected $\dot{\mathrm{VO}}_{2}$ level in humans), as previously reported $[45,47]$, with a $\mathrm{O}_{2}$ deficit reaching $300 \mathrm{ml} / \mathrm{kg}$ over a onehour period, up to three times the deficit reported in sheep or dogs during bleeding protocols leading to similar survival rates [2]. This large $\dot{\mathrm{VO}}_{2}$ deficit can be accounted for by the magnitude of blood flow redistribution in small $v s$ large animals $[42,48]$, a reduction in uncoupling protein activity, specific to small-sized mammals [49] and, eventually, a genuine reduction in oxidative mitochondrial activity resulting in lactic acidemia. Although extremely variable between animals, an elevation in blood level of TNF-alpha was found in all rats at the end of the bleeding period.
It is interesting to note that just like in hypoxiainduced hypometabolism [43] or when unloading venous return [50], ventilation decreased with $\dot{\mathrm{V}}_{2}$ and $\dot{\mathrm{V}} \mathrm{CO}_{2}$ but with a relative hyperventilation (Figure 2); this discrepancy between the drop in gas exchange rate and $\dot{\mathrm{V} I}$ resulted in all animals in a progressive reduction in $\mathrm{PaCO}_{2}$ and increase in $\mathrm{PaO}_{2}$ (Table 1). Finally, the relative higher values of $\dot{\mathrm{V}} \mathrm{CO}_{2}$ than $\dot{\mathrm{VO}}_{2}$ at the end of the bleeding protocol are likely to be accounted for by the equimolar transformation of the bicarbonate into $\mathrm{CO}_{2}$ (buffering of the developing metabolic acidosis). This could have resulted in a relative increase in $\mathrm{CO}_{2}$ output, akin to the rise in the respiratory quotient ratio typical of heavy exercise with hyperlactacidemia [51].

\section{Hemorrhagic shock and $\mathrm{H}_{2} \mathrm{~S}$}

$\mathrm{H}_{2} \mathrm{~S}$ has been shown to be present in the plasma at concentrations between 25 and $50 \mu \mathrm{M}$ and to increase up to $100 \mu \mathrm{M}$ in humans during various types of shock [18]. Plasma $\mathrm{H}_{2} \mathrm{~S}$ concentration in these patients [18] correlates with the severity of the shock. The very presence of $\mathrm{H}_{2} \mathrm{~S}$ in the plasma has already been challenged on methodological and physiological grounds $[20,28]$. Since the proteins present in the blood (hemoglobin) 
complex and/or catalyze very large amounts of sulfide [20], trivial levels of $\mathrm{H}_{2} \mathrm{~S}$, if any, are expected to be found in the plasma in baseline conditions, as shown by Furne et al. [28] and Whitfield et al. [20]. Whitfield et al. reported no measurable level of $\mathrm{H}_{2} \mathrm{~S}$ [20] after addition of $10 \mu \mathrm{M}$ of $\mathrm{H}_{2} \mathrm{~S}$ in rat blood before applying a method similar to that used in the present study. Besides, the levels reported both in baseline conditions and in shock $[11,16,18]$ appear to be higher than those expected to be found during severe $\mathrm{H}_{2} \mathrm{~S}$ intoxication [52], wherein mitochondrial activity is inhibited.

The method used to determine $\mathrm{H}_{2} \mathrm{~S}$ in previous studies $[11,16,18]$ was developed by Siegel et al. [36] and relies on the transformation of one molecule of $\mathrm{H}_{2} \mathrm{~S}$ and two molecules of $N, N$-dimethyl-p-phenylenediamine into one molecule of methylene blue (MB). $\mathrm{H}_{2} \mathrm{~S}$ concentration can then be determined by measuring the absorbance of the solution at $670 \mathrm{~nm}$ (methylene blue). One of the limits of this method is directly related to the fact that the absorbance is proportional to the concentration of a given molecule - which color is the complementary of the light wave absorbed - if and only if none of the incident light is scattered by dispersed particles or molecules. The presence of a minimal level of turbidity can alter the absorbance of light at any wavelength irrespective of the actual "color" of the plasma, unless a genuine peak of absorbance can be found between 600 and $700 \mathrm{~nm}$ (Figure 5). We found that, even after application of TCA to remove the proteins and multiple centrifugations, a significant absorbance can be found at $670 \mathrm{~nm}$. Using a broader spectrum of wavelengths, one can show that the Beer-Lambert law cannot be applied to identify small concentrations of $\mathrm{H}_{2} \mathrm{~S}$ in plasma. This is also illustrated in Figure 5 where the spectrum of absorbance of the plasma after reaction with the reagents to form MB is very different from that of a solution containing $\mathrm{H}_{2} \mathrm{~S}$ at the hypothetical concentration corresponding to a similar absorbance. These data suggest that if the method developed by Siegel is to be used in the plasma, determination of $\mathrm{H}_{2} \mathrm{~S}$ concentrations based on the absorbance of light at only $670 \mathrm{~nm}$ can be misleading, yielding to erroneous findings of $\mathrm{H}_{2} \mathrm{~S}$. This issue has already been highlighted by Hughes et al., who reported that the linear dependence of absorbance on the MB concentration was only valid for concentrations of $\mathrm{H}_{2} \mathrm{~S}$ much lower than those reported in all these studies; these authors also recommended the use of the spectra of absorbance between 550 and $700 \mathrm{~nm}$ [53]. Using a different method, based on the monobromobimane derivatization [54], Tokuda et al. reported $\mathrm{H}_{2} \mathrm{~S}$ plasma concentrations ranging at best between 2 to $4 \mu \mathrm{M}$, consistent with the present results, and more importantly that $\mathrm{H}_{2} \mathrm{~S}$ levels decreased, if anything, in endotoxic shock in mice [55]. Volatilization of $\mathrm{H}_{2} \mathrm{~S}$ observed by De Leon et al. [56] when samples are left in open air is unlikely to have occurred (see Method and Result sections); since we took the precaution to entirely fill all the vials and to cap them immediately, to prevent any significant volatilization. The procedure used for plasma $\mathrm{H}_{2} \mathrm{~S}$ measurements (including centrifugation) was applied as well to PBS solutions containing a known amount on $\mathrm{H}_{2} \mathrm{~S}$ (concentration $100 \mu \mathrm{M}$ ), and the level of $\mathrm{H}_{2} \mathrm{~S}$ was not affected. In addition, we previously found that using this procedure, $\mathrm{H}_{2} \mathrm{~S}$ concentration (in PBS or saline solution) remained stable with a few percent drop in concentration over one hour [30]. DeLeon et al. reported similar results when they took the precaution to close their chambers [56]. For the determination of the ability of the plasma and tissues to oxidize exogenous $\mathrm{H}_{2} \mathrm{~S}$, PBS solutions containing the same initial amount of $\mathrm{H}_{2} \mathrm{~S}$ were analyzed at the very same time as the plasma or supernatant; $\mathrm{H}_{2} \mathrm{~S}$ concentrations were unchanged in PBS within the two-minute period we chose for our determination and all results have been expressed in percentage of the concentration of $100 \mu \mathrm{M}$ present in the PBS solution analyzed at the same time and following the same procedure.

\section{Endogenous $\mathrm{H}_{2} \mathrm{~S}$ in the tissues, vitamin $\mathrm{B} 12$ and hemorrhagic shock}

There is a spontaneous oxidation/complexation of $\mathrm{H}_{2} \mathrm{~S}$ in the plasma and the supernatant of tissues, which was enhanced by $\mu \mathrm{M}$ concentrations of vitamin B12. The latter was obtained following intraperitoneal injection of vitamin B12 at a dose used during cyanide intoxication $\left(10^{6}\right.$ times the normal daily intake), as previously reported $[46,57,58]$. The kidney and heart were chosen as they are among the most important organs exposed to the consequences of hemorrhage-induced ischemia. In addition, our previous study [30] showed that the ability of tissue homogenates of these organs to oxidize $\mathrm{H}_{2} \mathrm{~S}$ was clearly enhanced in vitamin B12-treated rats. In that previous study, we found that vitamin B12 could oxidize large amounts of $\mathrm{H}_{2} \mathrm{~S}$ in direct relation to its concentration, likely due to the presence of oxidized cobalt [30]. We could establish that the presence of $10 \mu \mathrm{M}$ vitamin B12 was able to oxidize $20 \%$ of a $100 \mu \mathrm{M}$ solution of $\mathrm{H}_{2} \mathrm{~S}$; at $50 \mu \mathrm{M}$, about $80 \%$ of the $\mathrm{H}_{2} \mathrm{~S}$ was oxidized within five minutes. This is consistent with our present results, where vitamin $\mathrm{B} 12$ concentrations in the plasma were found to be about $180 \mu \mathrm{M}$ and could decrease the exogenous $\mathrm{H}_{2} \mathrm{~S}$ levels to $7.7 \pm 0.8 \mu \mathrm{M}$ (significantly lower than control plasma; initial concentration $100 \mu \mathrm{M}$ ), after two minutes. Similarly, about $50 \mu \mathrm{M}$ of hydroxocobalamin were found in our kidney homogenates, which in turn decreased $\mathrm{H}_{2} \mathrm{~S}$ concentrations by $65 \%$ ( $v s$ only $50 \%$ in control; initial concentration $100 \mu \mathrm{M})$. For the heart and, very likely, for some other tissues, the spectrophotometric method of detection of 
vitamin B12 was not sufficient to demonstrate the presence of vitamin B12 (the threshold is about $30 \mu \mathrm{M}$ [30]). Incidentally, $\mathrm{pM}$ - and not $\mu \mathrm{M}$ - concentrations of hydroxocobalamin are expected to be present in the body $[59,60]$; therefore, with the methodology used in the present study we were unable to demonstrate whether low $\mu \mathrm{M}$ concentrations of vitamin B12 were able to oxidize $\mathrm{H}_{2} \mathrm{~S}$ at the concentrations likely to be present in the heart [28]. This is a very important point to consider as our present results did not show that vitamin B12 was absent from the heart or could not oxidize sulfide, but within the very poor resolution of our method, no reliable conclusion could be drawn.

Hypoxic conditions have been proposed to decrease $\mathrm{H}_{2} \mathrm{~S}$ oxidation resulting in the accumulation of $\mathrm{H}_{2} \mathrm{~S}$ [23]. This increase in $\mathrm{H}_{2} \mathrm{~S}$ concentrations may, however, occur only if $\mathrm{PO}_{2}$ decreases to extremely low levels [24], similar to those expected to be found in the vicinity of the mitochondria, suggesting to Olson $[23,61]$ that the site of action for endogenous $\mathrm{H}_{2} \mathrm{~S}$ can only be the mitochondria. Studies trying to establish the actual amount of $\mathrm{H}_{2} \mathrm{~S}$ present and endogenously produced revealed that at best $\mathrm{nM}$ changes in $\mathrm{H}_{2} \mathrm{~S}$ concentrations can be observed [46]. We speculate that low levels of vitamin B12 could still be able to decrease such concentration of $\mathrm{H}_{2} \mathrm{~S}$ in our study [30].

The present study did not address the effect of reperfusion, wherein production of cytokines and oxidative stress are prominent. Patients or animal models who showed an increase in plasma $\mathrm{H}_{2} \mathrm{~S}$ concentrations $[16,18]$ were resuscitated, and the question of the putative role of endogenous $\mathrm{H}_{2} \mathrm{~S}$ will need to be tested during the critical period of reperfusion.

\section{Conclusions}

There is no evidence that $\mathrm{H}_{2} \mathrm{~S}$ can accumulate in the high micromolar range in the blood and tissues (extravascular compartment) during a lethal form of hemorrhagic shock. The presence of cobalt (hydroxocobalamin) did not affect any of the outcomes of the shock. These results imply that $\mathrm{H}_{2} \mathrm{~S}$ in the blood cannot be used as a marker of hemorrhagic shock. The hypothesis that $\mathrm{H}_{2} \mathrm{~S}$ could accumulate during hemorrhagic induced tissular hypoxia must be reconciled with the ability of tissues to oxidize $\mathrm{H}_{2} \mathrm{~S}$.

\section{Key messages}

- Even during a severe form of hemorrhagic shock in the rat, where a major $\mathrm{O}_{2}$ deficit is present, there is no evidence for an increase in $\mathrm{H}_{2} \mathrm{~S}$ concentration in the blood.

- Injection of high doses of hydroxocobalamin, although enhancing the ability of blood and kidneys to oxidize exogenous $\mathrm{H}_{2} \mathrm{~S}$ in vitro, does not improve the survival, $\mathrm{O}_{2}$ deficit, lactacidemia or TNF-alpha levels in this model of shock.

\section{Abbreviations}

ABP: arterial blood pressure; BTPS: body temperature and pressure saturated; f: breathing frequency; I.P.: intraperitoneal; MB: methylene blue; MOF: multiple organ failure; NS: non-significant; PBS: phosphate buffer saline; STPD: standard temperature and pressure: dry; TCA: trichloroacetic acid; $\dot{\text { V: }}$ inspiratory flow; $\dot{\mathrm{VI}}$ : minute ventilation; $\dot{\mathrm{V}} \mathrm{CO}_{2}$ : carbon dioxide production; $\dot{\mathrm{V}} \mathrm{O}_{2}$ : oxygen uptake; VT: tidal volume

\section{Authors' contributions}

$\mathrm{AV}$ and $\mathrm{PH}$ conceived of the study, performed the animal experiments, analyzed the data and drafted the manuscript. All authors read and approved the final manuscript.

\section{Competing interests}

The authors declare that they have no competing interests.

Received: 30 July 2012 Revised: 7 September 2012

Accepted: 2 October 2012 Published: 2 October 2012

\section{References}

1. Rixen D, Raum M, Holzgraefe B, Sauerland S, Nagelschmidt M, Neugebauer EA: A pig hemorrhagic shock model: oxygen debt and metabolic acidemia as indicators of severity. Shock 2001, 16:239-244

2. Rixen D, Siegel JH: Bench-to-bedside review: oxygen debt and its metabolic correlates as quantifiers of the severity of hemorrhagic and post-traumatic shock. Crit Care 2005, 9:441-453.

3. Siegel JH, Fabian M, Smith JA, Kingston EP, Steele KA, Wells MR, Kaplan LJ: Oxygen debt criteria quantify the effectiveness of early partial resuscitation after hypovolemic hemorrhagic shock. J Trauma 2003, 54:862-880, discussion 880 .

4. Dunham CM, Siegel JH, Weireter L, Fabian M, Goodarzi S, Guadalupi P, Gettings L, Linberg SE, Vary TC: Oxygen debt and metabolic acidemia as quantitative predictors of mortality and the severity of the ischemic insult in hemorrhagic shock. Crit Care Med 1991, 19:231-243.

5. Crowell JW, Smith EE: Oxygen deficit and irreversible hemorrhagic shock. Am J Physiol 1964, 206:313-316.

6. Shoemaker WC, Appel PL, Kram HB: Role of oxygen debt in the development of organ failure sepsis, and death in high-risk surgical patients. Chest 1992, 102:208-215.

7. Dewar D, Moore FA, Moore EE, Balogh Z: Postinjury multiple organ failure. Injury 2009, 40:912-918.

8. Yao YM, Redl H, Bahrami S, Schlag G: The inflammatory basis of trauma/ shock-associated multiple organ failure. Inflamm Res 1998, 47:201-210.

9. Jarrar D, Chaudry $H$, Wang P: Organ dysfunction following hemorrhage and sepsis: mechanisms and therapeutic approaches (Review). Int J Mol Med 1999, 4:575-583.

10. Jastrow KM, Gonzalez EA, McGuire MF, Suliburk JW, Kozar RA, lyengar S, Motschall DA, McKinley BA, Moore FA, Mercer DW: Early cytokine production risk stratifies trauma patients for multiple organ failure. J Am Coll Surg 2009, 209:320-331.

11. Mok YY, Atan MS, Yoke Ping C, Zhong Jing W, Bhatia M, Moochhala S, Moore PK: Role of hydrogen sulphide in haemorrhagic shock in the rat: protective effect of inhibitors of hydrogen sulphide biosynthesis. $\mathrm{Br} \mathrm{J}$ Pharmacol 2004, 143:881-889.

12. Mok YY, Moore PK: Hydrogen sulphide is pro-inflammatory in haemorrhagic shock. Inflamm Res 2008, 57:512-518.

13. Wagner F, Asfar P, Calzia E, Radermacher P, Szabo C: Bench-to-bedside review: hydrogen sulfide - the third gaseous transmitter: applications for critical care. Crit Care 2009, 13:213.

14. Collin M, Anuar FB, Murch O, Bhatia M, Moore PK, Thiemermann C: Inhibition of endogenous hydrogen sulfide formation reduces the organ injury caused by endotoxemia. Br J Pharmacol 2005, 146:498-505. 
15. Collin M, Thiemermann C: Hydrogen sulfide and sulfite: novel mediators in the pathophysiology of shock and inflammation. Shock 2005, 24:595-596.

16. Li L, Bhatia M, Zhu YZ, Zhu YC, Ramnath RD, Wang ZJ, Anuar FB, Whiteman M, Salto-Tellez M, Moore PK: Hydrogen sulfide is a novel mediator of lipopolysaccharide-induced inflammation in the mouse. FASEB J 2005, 19:1196-1198.

17. Hui $Y$, Du J, Tang C, Bin G, Jiang H: Changes in arterial hydrogen sulfide $(\mathrm{H}(2) \mathrm{S})$ content during septic shock and endotoxin shock in rats. $J$ Infect 2003, 47:155-160.

18. Goslar T, Mars T, Podbregar M: Total plasma sulfide as a marker of shock severity in nonsurgical adult patients. Shock 2011, 36:350-355.

19. Olson KR, Healy MJ, Qin Z, Skovgaard N, Vulesevic B, Duff DW, Whitfield NL, Yang G, Wang R, Perry SF: Hydrogen sulfide as an oxygen sensor in trout gill chemoreceptors. Am J Physiol Regul Integr Comp Physiol 2008, 295: R669-680.

20. Whitfield NL, Kreimier EL, Verdial FC, Skovgaard N, Olson KR: Reappraisal of $\mathrm{H} 2 \mathrm{~S} /$ sulfide concentration in vertebrate blood and its potential significance in ischemic preconditioning and vascular signaling. Am J Physiol Regul Integr Comp Physiol 2008, 294:R1930-1937.

21. Peng YJ, Nanduri J, Raghuraman G, Souvannakitti D, Gadalla MM, Kumar GK, Snyder SH, Prabhakar NR: H2S mediates $\mathrm{O} 2$ sensing in the carotid body. Proc Natl Acad Sci USA 2010, 107:10719-10724.

22. Olson KR: Hydrogen sulfide and oxygen sensing: implications in cardiorespiratory control. J Exp Biol 2008, 211:2727-2734.

23. Olson KR: Hydrogen sulfide is an oxygen sensor in the carotid body. Respir Physiol Neurobiol 2011, 179:103-110.

24. Van de Louw A, Haouzi P: Inhibitory effects of hyperoxia and methemoglobinemia on $\mathrm{H}(2) \mathrm{S}$ induced ventilatory stimulation in the rat. Respir Physiol Neurobiol 2012, 181:326-334.

25. Haouzi P: Sulfide and methemoglobinemia. Respir Physiol Neurobiol 2011, 179:119-120.

26. Haouzi $P$, Bell H, Philmon M: Hydrogen sulfide oxidation and the arterial chemoreflex: effect of methemoglobin. Respir Physiol Neurobiol 2011, 177:273-283

27. Hegde $A$, Bhatia M: Hydrogen sulfide in inflammation: friend or foe? Inflamm Allergy Drug Targets 2011, 10:118-122.

28. Furne J, Saeed A, Levitt MD: Whole tissue hydrogen sulfide concentrations are orders of magnitude lower than presently accepted values. Am J Physiol Regul Integr Comp Physiol 2008, 295:R1479-1485.

29. Haggard HW: The fate of sulfides in the blood. J Biol Chem 1921, 49:519-529.

30. Van de Louw A, Haouzi P: Ferric iron and cobalt (III) compounds to safely decrease H2S in the body? Antioxid Redox Signal 2012

31. Haouzi $P$, Bell H, Van de Louw A: Hypoxia-induced arterial chemoreceptor stimulation and hydrogen sulfide: too much or too little? Respir Physiol Neurobiol 2011, 179:97-102

32. Chai $W$, Wang $Y$, Lin JY, Sun $X D$, Yao LN, Yang $Y H$, Zhao $H$, Jiang $W$, Gao CJ, Ding Q: Exogenous hydrogen sulfide protects against traumatic hemorrhagic shock via attenuation of oxidative stress. J Surg Res 2011, 176:210-219

33. Morrison ML, Blackwood JE, Lockett SL, Iwata A, Winn RK, Roth MB: Surviving blood loss using hydrogen sulfide. J Trauma 2008, 65:183-188.

34. Ganster F, Burban $M$, de la Bourdonnaye M, Fizanne L, Douay O, Loufrani L, Mercat A, Cales P, Radermacher P, Henrion D, Asfar P, Meziani F: Effects of hydrogen sulfide on hemodynamics, inflammatory response and oxidative stress during resuscitated hemorrhagic shock in rats. Crit Care 2010, 14:R165.

35. Drabek T: Hydrogen sulfide-curiouser and curiouser! Crit Care Med 2012, 40:2255-2256.

36. Siegel LM: A direct microdetermination for sulfide. Anal Biochem 1965 , 11:126-132.

37. Peto R, Pike MC, Armitage P, Breslow NE, Cox DR, Howard SV, Mantel N, McPherson K, Peto J, Smith PG: Design and analysis of randomized clinical trials requiring prolonged observation of each patient. II. analysis and examples. Br J Cancer 1977, 35:1-39.

38. Taylor JH, Beilman GJ, Conroy MJ, Mulier KE, Myers D, Gruessner A, Hammer BE: Tissue energetics as measured by nuclear magnetic resonance spectroscopy during hemorrhagic shock. Shock 2004, 21:58-64.

39. Drabek T, Kochanek PM, Stezoski J, Wu X, Bayir H, Morhard RC, Stezoski SW, Tisherman SA: Intravenous hydrogen sulfide does not induce hypothermia or improve survival from hemorrhagic shock in pigs. Shock 2011, 35:67-73

40. Crippen D, Safar P, Snyder C, Porter L: Dying pattern in volume-controlled hemorrhagic shock in awake rats. Resuscitation 1991, 21:259-270.

41. Van der Linden P, Gilbart E, Engelman E, Schmartz D, de Rood M, Vincent JL: Comparison of halothane, isoflurane, alfentanil, and ketamine in experimental septic shock. Anesth Analg 1990, 70:608-617.

42. Armstrong JM, Lefevre-Borg F, Scatton B, Cavero I: Urethane inhibits cardiovascular responses mediated by the stimulation of alpha-2 adrenoceptors in the rat. J Pharmacol Exp Ther 1982, 223:524-535.

43. Mortola JP: Implications of hypoxic hypometabolism during mammalian ontogenesis. Respir Physiol Neurobiol 2004, 141:345-356.

44. Gautier $\mathrm{H}$ : Interactions among metabolic rate, hypoxia, and control of breathing. J Appl Physiol 1996, 81:521-527.

45. Frappell P, Lanthier C, Baudinette RV, Mortola JP: Metabolism and ventilation in acute hypoxia: a comparative analysis in small mammalian species. Am J Physiol 1992, 262:R1040-1046.

46. Haouzi P: Ventilatory and metabolic effects of exogenous hydrogen sulfide. Respir Physiol Neurobiol 2012.

47. Shepherd RE, Gollnick PD: Oxygen uptake of rats at different work intensities. Pflugers Arch 1976, 362:219-222.

48. Shepherd AP, Pawlik W, Mailman D, Burks TF, Jacobson ED: Effects of vasoconstrictors on intestinal vascular resistance and oxygen extraction. Am J Physiol 1976, 230:298-305

49. Janssen BJ, De Celle T, Debets JJ, Brouns AE, Callahan MF, Smith TL: Effects of anesthetics on systemic hemodynamics in mice. Am J Physiol Heart Circ Physiol 2004, 287:H1618-1624.

50. Haouzi P, Bell HJ: Respiratory effects of changing the volume load imposed on the peripheral venous system. Respir Physiol Neurobiol 2010, 171:175-180.

51. Beaver WL, Wasserman K, Whipp BJ: A new method for detecting anaerobic threshold by gas exchange. J Appl Physiol 1986, 60:2020-2027.

52. Kage S, Kashimura S, Ikeda H, Kudo K, Ikeda N: Fatal and nonfatal poisoning by hydrogen sulfide at an industrial waste site. J Forensic Sci 2002, 47:652-655

53. Hughes MN, Centelles MN, Moore KP: Making and working with hydrogen sulfide: The chemistry and generation of hydrogen sulfide in vitro and its measurement in vivo: a review. Free Radic Biol Med 2009, 47:1346-1353.

54. Wintner EA, Deckwerth TL, Langston W, Bengtsson A, Leviten D, Hill P, Insko MA, Dumpit R, VandenEkart E, Toombs CF, Szabo C: A monobromobimane-based assay to measure the pharmacokinetic profile of reactive sulphide species in blood. Br J Pharmacol 2010, 160:941-957.

55. Tokuda K, Kida K, Marutani E, Crimi E, Bougaki M, Khatri A, Kimura H, Ichinose F: Inhaled hydrogen sulfide prevents endotoxin-induced systemic inflammation and improves survival by altering sulfide metabolism in mice. Antioxid Redox Signal 2012, 17:11-21.

56. Deleon ER, Stoy GF, Olson KR: Passive loss of hydrogen sulfide in biological experiments. Anal Biochem 2012, 421:203-207.

57. Truong DH, Mihajlovic A, Gunness P, Hindmarsh W, O'Brien PJ: Prevention of hydrogen sulfide ( $\mathrm{H} 2 \mathrm{~S})$-induced mouse lethality and cytotoxicity by hydroxocobalamin (vitamin B(12a)). Toxicology 2007, 242:16-22.

58. de La Coussaye JE, Houeto P, Sandouk P, Levillain P, Sassine A, Riou B: Pharmacokinetics of hydroxocobalamin in dogs. J Neurosurg Anesthesiol 1994, 6:111-115.

59. Slot WB, Merkus FW, Van Deventer SJ, Tytgat GN: Normalization of plasma vitamin B12 concentration by intranasal hydroxocobalamin in vitamin B12-deficient patients. Gastroenterology 1997, 113:430-433.

60. Linnell JC, Mackenzie HM, Wilson J, Matthews DM: Patterns of plasma cobalamins in control subjects and in cases of vitamin B12 deficiency. J Clin Pathol 1969, 22:545-550.

61. Olson KR: "Hydrogen sulfide oxidation and the arterial chemoreflex: effect of methemoglobin" by Haouzi et al. [Respir. Physiol. Neurobiol. (2011)]. Respir Physiol Neurobiol 2011, 179:121, author reply 119-120.

doi:10.1186/cc11661

Cite this article as: Van de Louw and Haouzi: Oxygen deficit and $\mathrm{H}_{2} \mathrm{~S}$ in hemorrhagic shock in rats. Critical Care 2012 16:R178. 